\title{
Prevalence of Endoparasitic Infection in Free Ranging Peacocks of Southern Tamil Nadu, India
}

\author{
R.S. Kathiravan ${ }^{1}$, P. Ramachandran ${ }^{2 *}$, S. Shanmuganathan ${ }^{3}$, A. Karthikeyan ${ }^{3}$, \\ N. Sathiyamoorthy ${ }^{1}$, S.K. Gollapalli ${ }^{4}$, R. Silambarasan ${ }^{5}$, D. Bhinsara ${ }^{3}$ and E. Madesh ${ }^{3}$ \\ ${ }^{1}$ Veterinary College and Research Institute, Namakkal, Tamil Nadu-637002, India \\ ${ }^{2}$ Wild animal Veterinarian, Animal Care Trust, Rajapalayam, Tirunelveli-626117, T.N., India \\ ${ }^{3}$ Indian Veterinary Research Institute, Izatnagar-243122, U.P., India \\ ${ }^{4}$ College of Vetereinary Science, Sri Venkateswara Veterinary University, \\ Tirupati-517502, A.P., India \\ ${ }^{5}$ Veterinary officer, Chettinad Stud and Agricultural Farm, Chennai-600067, Tamil Nadu, India \\ *Corresponding author
}

\section{A B S T R A C T}

The objective of this study was to investigate the distribution and prevalence of gastrointestinal parasites in wild free ranging peafowls living in Virudhunagar and Tirunelveli

Keywords districts of Southern Tamilnadu, through cross-sectional survey. A total of 72 freshly voided faecal samples were collected randomly from wild free ranging peafowls of either sex and of different age groups and were examined by direct faecal smear; flotation and

Endoparasites, Pea Fowls, Eimeria spp.

\section{Article Info}

Accepted:

04 September 2017

Available Online:

10 October 2017 sedimentation techniques to detect parasitic oocysts and/or eggs. Out of this 49 were found to be positive for parasitic infection. The data on the distribution of the various parasitic species in the wild free ranging peafowls showed that Eimeria spp were the most common (43\%) particularly E. mayurai and E. pavonis. The other detected worm species and their respective frequencies were: Hymenolepis spp (4.16\%), Ascardia spp (6.9\%), Strongyloides spp (4.16\%) and Strongyles $(2.77 \%)$. The present study revealed the high prevalence of coccidial infections in the national bird of India, besides other helminths. Further, more detailed systematic epidemiological studies are warranted on parasitic infections infecting peafowls as these infections are chronic in nature and detrimental for survival.

\section{Introduction}

Peafowls are grouped under the order Galliformes in the family Phasianidae with the genera Pavo and Afropavom. The wild and domesticated peafowls are prone to many bacterial, viral and parasitic infectious diseases (Hopkins, 1997). Various factors are contributing for infections in peafowls such as unnatural habitat, the human encroachment of the forest lands (Perrins, 1990), availability of vectors and intermediate hosts and urbanization etc. Further, peafowls usually predate various intermediate hosts of parasites that plays pivotal role in transmission of parasitic diseases, particularly helminths. The peafowl population is under severe threat not only due to habitat destruction and poaching, the infections particularly parasitic infections may be also an important etiological factor. 
The parasitic infections are chronic in nature, causing anorexia, malnutrition related diseases, which makes the birds immunecompromised, and prone for viral and secondary bacterial infections (Steiner and Davis, 1981). The endoparasites mainly infest the gastro-intestinal tract of the bird and infected birds may develop enteritis, emaciation, depression, anorexia, anemia, and death (Forrester et al., 1978). Coccidia, gastro-intestinal nematodes and cestodes are major endoparasites infecting peafowls (Titilincu et al., 2009; Jaiswal et al., 2013). The main mode of transmission of coccidiosis is by ingesting sporulated oocysts, which are frequently contaminating feeding habitants of wild birds. The sporulated Eimeria spp. oocysts survive up to 8 months (Svensson, 1997). The helminths are other major group of parasites infecting wild birds including peafowls through oral-faecal route by ingesting infective stages and intermediate hosts. The endoparasitic infections of wild and domestic peafowls have significant role in parasitic zoonoses that require the attention towards public health concern and economic importance (Williams, 1978; Macpherson et al., 2000). Moreover, the differential diagnosis of the endoparasitic infections in peafowls will rule out the major etiological agents of parasitic zoonoses. On these lines, the present study was carried out with the initial aim of investigating endoparasitic infestation in free range Indian peafowls, which may provide way for further characterization of various parasites and it may also enlighten the formulation of control programme strategies.

\section{Materials and Methods}

A total of 72 freshly voided faecal samples of peafowls were collected in a labelled container from the agricultural fields encroached by the wild free ranging peafowls in the areas of Virudhunagar and Tirunelveli districts of Southern Tamilnadu state in India. The samples were collected randomly from both sex and different age group of birds. The faecal samples were brought to the laboratory and examined immediately or kept $4^{\circ} \mathrm{C}$ till examination (maximum three days). All the samples were examined by smearing method, salt floatation and sedimentation techniques. The positive samples were subjected for modified McMaster quantitative method for quantification of parasitic oocysts and/or eggs (Hodgson, 1970; Soulsby, 1982; Fowler, 1986). The various parasitic infections were identified based on morphological keys of the eggs and oocysts (Pellerdy, 1974; Soulsby, 1982; Sloss et al., 1994; Jaiswal et al., 2013).

\section{Results and Discussion}

The most of the faecal samples were fresh and moist at the time of collection and few were semisolid/diarrhoeic in condition with extremely foul smelling ( $\mathrm{N}=23)$ (Table 1). Thirty one samples (43\%) were found positive for Eimeria spp, and all the positive samples were infected with two types of Eimeria spp, i.e. E.mayurai and E. Pavonis (Figs. 1-2). The OPG (oocyst per gram) count varied from 5600- 23,300 (Average. $14,967 \pm 597.53)$. The micrometry analysis showed the average oocysts size varied from $16-31 \times 11-27 \mu \mathrm{m}$. The coccidial infections are highly pathogenic to peacocks and in favourable conditions morbidity reach up to 50\% (Musaev et al., 1991). Generally, the predilection site for coccidial infections is the small intestines and its lifecycle continued by oral-faecal ingestion with sporulated oocyst (Burr, 1987). The other than Eimeria spp, the peafowls are also infected commonly by other coccidians such as Isosopra, Tyzzeria and Wenyonella (Papini et al., 2012). In an earlier study reported that eight species of Eimeria were infecting peacocks (Titilincu et al., 2009). However, in Indian scenario, five species of Eimeria were reported namely $E$. 
pavonina, E. mandali, E. pavonis, E. mayurai and E. patnaiki by various workers (Banik and Ray, 1964; Mandal, 1965; Bhatia and Pande, 1966; Ray, 1966; Jaiswal et al., 2013).

The other notable parasitic infections identified were Hymenolepis spp (4.16\%), Ascardia spp (6.9\%), Strongyloides spp (4.16\%) and Strongyles (2.77\%) (Figs. 3-6). The Ascarid eggs showed characteristic mammalated outermost thick layer, single cell stage and the size of the egg was approximately $50 \times 75 \mu \mathrm{m}$ with light brownish colour. Strongyloides eggs were ellipsoid in shape containing developed larvae and the size of the eggs was around $45 \times 80 \mu \mathrm{m}$. The Hymenolepis egg was roughly round shape, around $60-70 \mu \mathrm{m}$ thick size, double layered outer cover contained characteristic hexacanth embryo. The Strongylus eggs were oval in shape, thin walled shell and embryo was in eight cell stage. As peafowls are feeding on free range in agricultural areas, there may be chances to get infected with helminths through ingesting of transport hosts i.e. earthworms (Soulsby, 1982). The strongyles and strongyloides are geo-helminths, the infective $\mathrm{L}_{3}$ (third stage larvae) readily present in the field. Therefore, peafowls are prone for these infections frequently. Previously many researchers reported helminth infections in peacocks from free range as well as captive areas (Sakamoto and Yamashita, 1970; Patel et al., 2000; Freitas et al., 2002; Titilincu et al., 2009; Jaiswal et al., 2013).

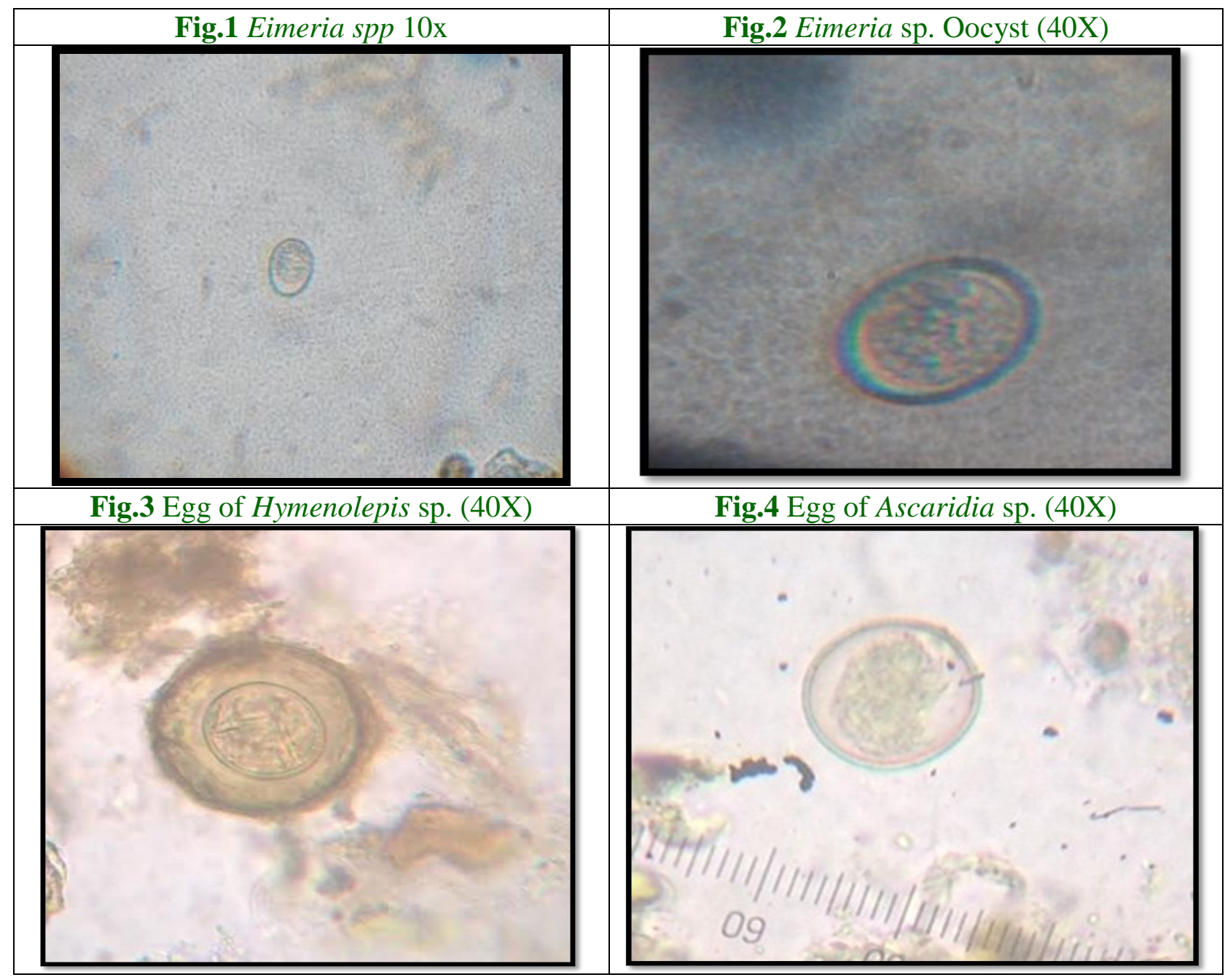




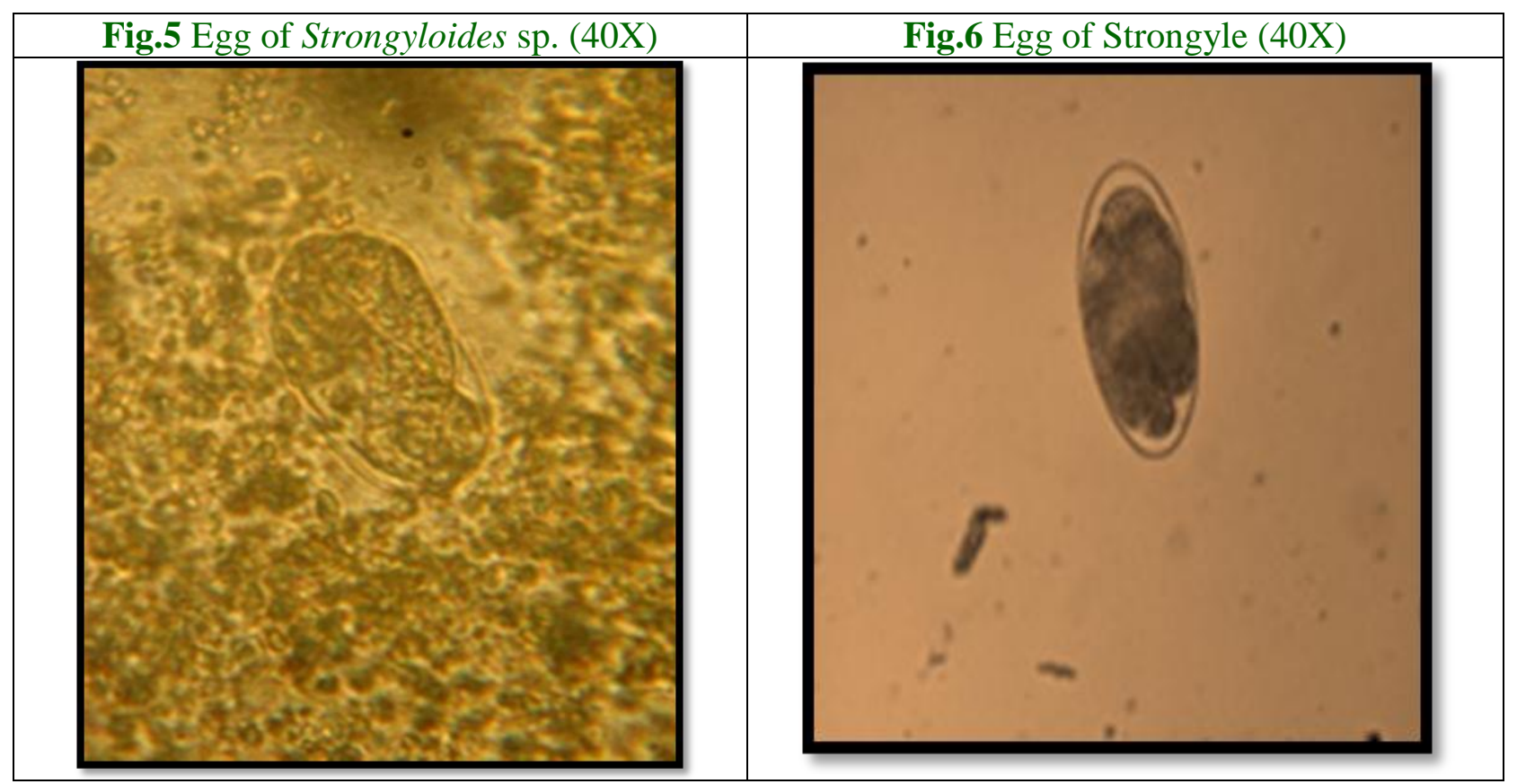

Fig.7 Graphical representation of endoparasitic infestation in peafowls

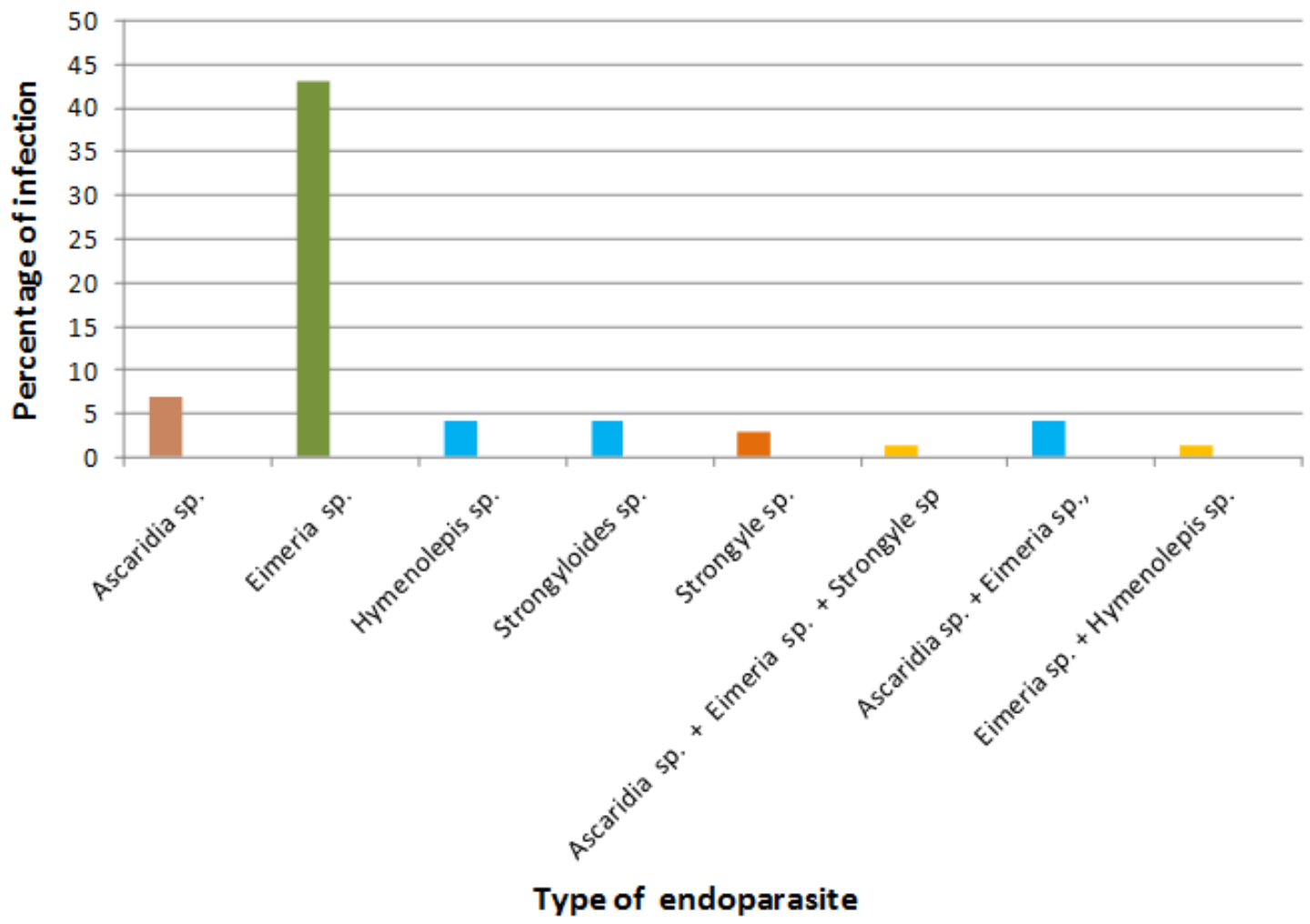


Table.1 Prevalence of endoparasitic infestation in faecal samples of free ranging peafowls

\begin{tabular}{|l|l|c|c|}
\hline S. No. & Endoparasite & No. of Positive samples & Percentage of Positive samples \\
\hline 1. & Ascaridia sp. & 5 & $6.94 \%$ \\
\hline 2. & Eimeria $\mathrm{sp}$. & 31 & $43.0 \%$ \\
\hline 3. & Hymenolepis $\mathrm{sp}$. & 3 & $4.16 \%$ \\
\hline 4. & Strongyloides $\mathrm{sp}$. & 3 & $4.16 \%$ \\
\hline 5. & Strongyle $\mathrm{sp}$. & 2 & $2.77 \%$ \\
\hline 6. & $\begin{array}{l}\text { Ascaridia } \mathrm{sp} .+ \text { Eimeria } \text { sp. }+ \\
\text { Strongyle } \mathrm{sp}\end{array}$ & 1 & $1.38 \%$ \\
\hline 7. & Ascaridia sp. + Eimeria sp., & 3 & $4.16 \%$ \\
\hline 8. & Eimeria $\mathrm{sp} .+$ Hymenolepis $\mathrm{sp}$. & 1 & $1.38 \%$ \\
\hline
\end{tabular}

It was observed that mixed infections, frequently in few peacocks particularly, Eimeria spp. with Ascaridia spp and Eimeria spp. with Strongyles. Our findings are similar with earlier reports as these birds are more prone to mixed parasitic infections (Muraleedharan et al., 1990; Reddy et al., 1992; Titilincu et al., 2009; Jaiswal et al., 2013). Normally, endoparasitic infections are chronic and cause discomfort, anorexia and unthriftness which lead to severe loses in wildlife population (Steiner and Davis, 1981). In many situations, the infections may be zoonotic when these birds are entering in to the human and agricultural habitats (Daszak et al., 2000).

The presence of Hyemenolepis species in the faecal samples of the peafowls observed in the present study is of major public health concern as samples were collected from the humanagricultural habitats. The human engaging in the agricultural works may have chance of getting infection with this zoonotic parasite. Among cestodes, the occurrence of Hyemenolepis infection and some unidentified cestode eggs in Indian peafowls were also reported earlier from India (Jaiswal et al., 2013).

In conclusion, parasitic infections are very common in free ranged peafowls. However, the great concern is intensity of infection, particularly coccidiosis.

\section{References}

Banik, D.C., and Ray, H.N. 1964. On a new coccidium Eimeria mandali n. sp. from peacock. Bull. Calcutta. Sch. Trop. Med., $12: 27$.

Bhatia, B.B., and Pande, B.P. 1966. A new coccidium, Eimeria mayurai (Sporozoa: Eimeriidae) from the common peafowl Pavo cristatus L. Proc. Natl. Acad. Sci. India. 36: 39-42.

Burr, E.W., 1987. Companion bird medicine. Iowa State University, Press, USA. 132 133.

Daszak, P., Cunningham, A.A. and Hyatt, A.D. 2000. Emerging infectious diseases of wildlife-threats to biodiversity and human health. Science, 287: 443-449.

Forrester, D.J., Carpenter JW, Blankinship JR (1978) Coccidia of whooping cranes. Journal of Wildlife Diseases 14:24-27.

Fowler, M.E., 1986. Zoo and Wild Animal Medicine. Second edn. W.B. Saunders Company, Philadelphia. Pp.471.

Freitas, M.F.L., Oliveira, J.B., Cavalcanti, M.D.B., Leite, A.S., Magalhaes, V.S., Oliveira, R.A., and Evencio-Sobrino, A. 2002. Gastrointestinal parasites of captive wild birds in pernambuco state, Brazil. Parasitol Latinoam., 57: 50-54

Hodgson, J.N., 1970. Coccidiosis: oocyst counting technique for coccidiostat evaluation. Exp. Parasitol., 28:99-102.

Hopkins, C., 1997. Peafowl Husbandry. Game 
Bird and Conservationists Gazette, 6: 3739.

Jaiswal, A.K., Sudan, V., Shanker, D, and Kumar, P. 2013. Endoparasitic infections in Indian peacocks (Pavo cristatus) of Veterinary College Campus, Mathura. $J$. Parasit. Dis., 37(1): 26-28.

Macpherson, C.N.L., Gottstein, Geert, S. 2000. Parasitic food-borne and water-borne zoonoses. Rev. Sci. tech. Off. Int. Epiz., 19 (1): 240-258.

Mandal, A.K., 1965. Studies on some aspects of avian coccidian (Protozoa: Sporozoa). 3. Five new species of the genus Eimeria schnedier, and a new subspecies of Eimeria roscoviensis (Labbe). Proc. Zool. Soc. (Calcutta) 18:47-57.

Muraleedharan, K., Iswaraiah, V., Ziauddin, S.K. and Srinivasan, K. 1990. A survey of gastrointestinal parasites of mammals of zoological gardens at Mysore. Mysore J. Agri. Sci., 24: 250-52

Musaev, M.A., Gadjiev, A.T., Yolchiyev, Y.Y., Vahidova, S.M. and Mustafaeva, Z.A. 1991. Parasite of domestic fowl in Azerbaijan and method of control. Elm. Baku. pp: 160.

Papini, R., Girivetto, M., Marangi, M., Mancianti, F. and Giangaspero, A. 2012. Endoparasite infections in pet and zoo birds in Italy. The Scientific World Journal, 2012: 253127.

Patel, P.V., Patel, A.I., Sahu, R.R. and Vyas, R. 2000. Prevalence of Gastro-intestinal parasites in captive birds of Gujarat zoos. Zoo's print journal. 15(7): 295-296.

Pellerdy. L., 1974. Coccidia and Coccidiosis Akad. kiado. Budapest. 193-330.

Perrins, C.M., 1990. The illustrated encyclopedia of birds, Headline book publishers, London, pp.40-41: 148-149, 152-153

Ray, H.N., 1966. Remarks on Eimeria pavonis $n . s p$. From Indian peacock (Pavo cristatus). Indian J. Microbiol., 6: 51-52.

Reddy, N.R., Jaya Gopala, Jagannath, M.S., D'souza, P.E., Rahman, A. and Basavarajappa. 1992. Prevalence of gastrointestional parasites in wild mammals and captive birds at Bannerghatta National Park, Bangalore. Indian J. Anim. Sci. 62(11):1046-1048.

Sakamoto, T., and Yamashita, J. 1970. Studies on Strongiloidiasis of the Peacock, Japanese J. Vet. Res., 18: 163- 171.

Sloss, W.M., Kemp, R.L. and Zajac, A.M. 1994. Veterinary clinical parasitology. Sixth edn. Iowa State University press, Iowa, USA. Pp.80-85

Soulsby, E.J.L., 1982. Helminths, Arthropods and Protozoa of domesticated animals. Seventh edn. ELBS, London. Pp. $1-772$.

Steiner, C.V., and Davis, R.B. 1981. Caged bird medicine. Iowa state university press. Ames, Iowa. Pp 31-38.

Svensson, C., 1997. The survival and transmission of oocysts of Eimeria alabamensis in hay. Vet. Parasitol. 69: 211-218.

Titilincu, A., Mircean, V., Iovu, B.A., Ungureanu, R. and Cozma, V. 2009. Prevalence of endoparasites in peacocks (Pavo cristatus). Sc. Parasitol., 1-2:101105.

Williams, R.B., 1978. Notes on some Coccidia of peafowl, pheasants and chickens. Vet. Parasitol, 4:193-197.

\section{How to cite this article:}

Kathiravan, R.S., P. Ramachandran, S. Shanmuganathan, A. Karthikeyan, N. Sathiyamoorthy, S.K. Gollapalli, R. Silambarasan, D. Bhinsara and Madesh, E. 2017. Prevalence of Endoparasitic Infection in Free Ranging Peacocks of Southern Tamil Nadu, India. Int.J.Curr.Microbiol.App.Sci. 6(10): 366-371. doi: https://doi.org/10.20546/ijcmas.2017.610.045 